\title{
OFFSHORING POLLUTION WHILE OFFSHORING PRODUCTION?
}

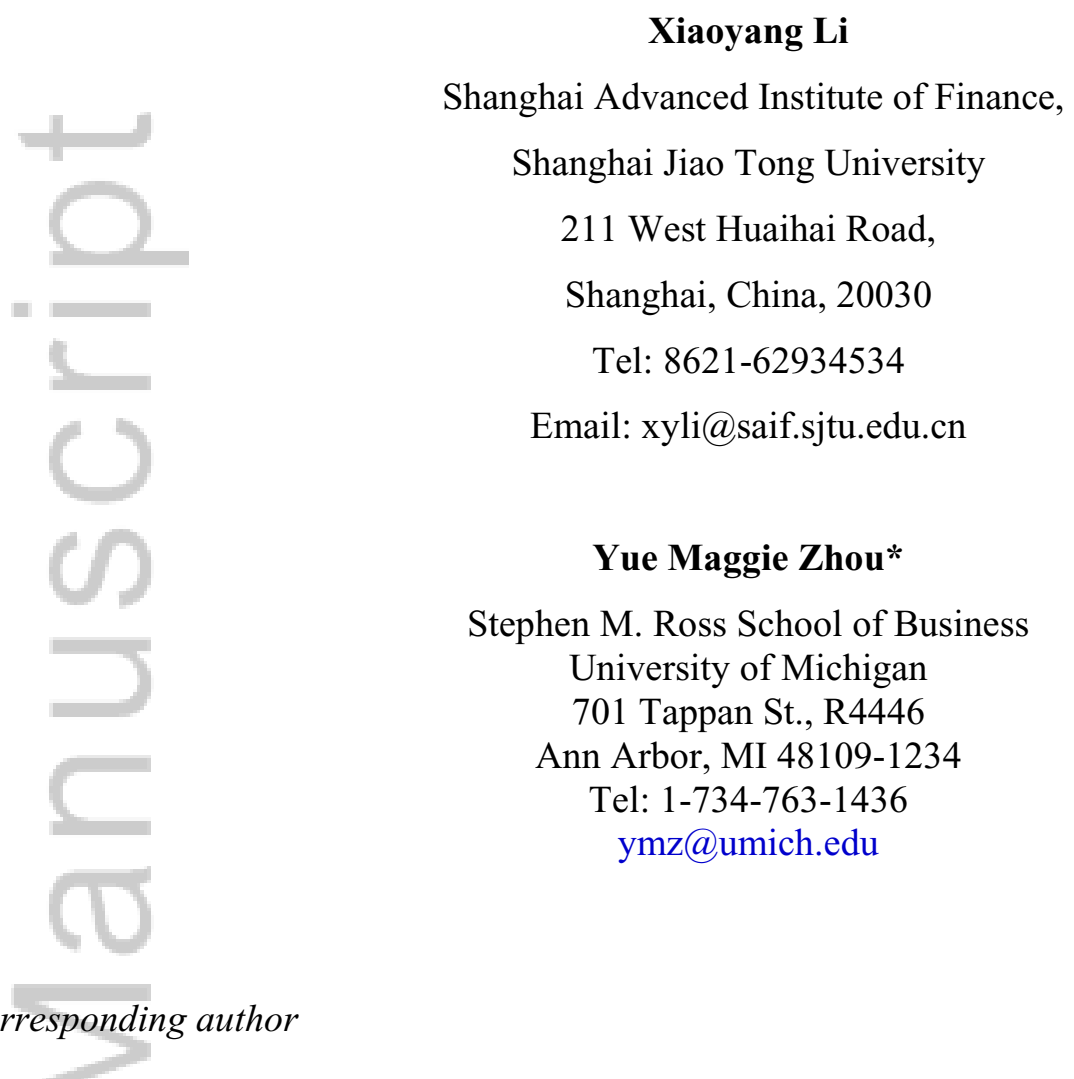

Running head: Offshoring Pollution while Offshoring Production?

Keywords: environmental strategy, pollution haven, offshoring, institutional arbitrage, corporate social responsibility

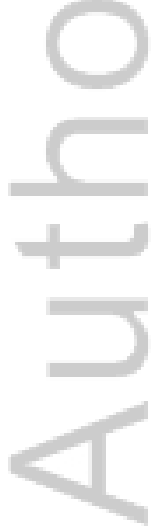

This is the author manuscript accepted for publication and has undergone full peer review but has not been through the copyediting, typesetting, pagination and proofreading process, which may lead to differences between this version and the Version of Record. Please cite this article as doi: $10.1002 / \mathrm{smj} .2656$

This article is protected by copyright. All rights reserved. 


\section{OFFSHORING POLLUTION WHILE OFFSHORING PRODUCTION?}

Abstract: We examine the role of firm strategy in the global effort to combat pollution. We find that U.S. plants release less toxic emissions when their parent firm imports more from low-wage countries (LWCs). Consistent with the Pollution Haven Hypothesis, goods imported by U.S. firms from LWCs are in more pollution-intensive industries. U.S. plants shift production to less pollution-intensive industries, produce less waste, and spend less on pollution abatement when their parent imports more from LWCs. The negative impact of LWC imports on emissions is stronger for U.S. plants located in counties with greater institutional pressure for environmental performance, but weaker for more-capable U.S. plants and firms. These results highlight the role of local institutions and firm capability in explaining firms' offshoring and environmental strategy.

Keywords: environmental strategy, pollution haven, offshoring, institutional arbitrage, corporate social responsibility

Managerial summary: Using confidential trade, production, and pollution data of more than 8,000 firms and 18,000 plants from the U.S. Census Bureau for years 1992-2009, we find that U.S. plants release less toxic emissions when their parent firm imports more from low-wage countries (LWCs). In addition, goods imported by U.S. firms from LWCs are in more pollutionintensive industries. U.S. plants shift production to less pollution-intensive industries, produce less waste, and spend less on pollution abatement when their parent imports more from LWCs. However, not all U.S. firms choose to "offshore pollution." U.S. plants located in counties with greater institutional pressure for environmental performance offshore more, but more-capable U.S. plants and firms offshore less. 


\section{INTRODUCTION}

The global effort to combat pollution has gained tremendous momentum in recent years. The United States and China, the two largest emitters of greenhouse gas, issued a joint announcement in 2014 to strengthen bilateral cooperation, including joint technological initiatives, research efforts, and economic policies, to tackle climate change (The White House, 2014). One hundred ninety-six countries attending the 2015 United Nations Climate Change Conference voted to adopt a joint agreement to curb global warming (NPR, 2015). India and France launched a global alliance to mobilize investments from rich countries to develop solar power around the world, especially in sun-rich but cash-poor tropical countries (Financial Times, 2015). Participation in these global initiatives is not always welcomed at home, however. Only recently have politicians, the media, and large businesses in the United States started to openly accept climate change and global warming concerns. Other critics are content with the empirical evidence that strict environmental regulations and informal institutional pressure in the United States have already significantly improved its environment (Chay \& Greenstone, 2003; Levinson, 2009; Shapiro \& Walker, 2014). Significant portions of Americans still think their government should not take responsibility for other countries' environmental problems.

We examine these critical views by focusing on the role of firm strategy in the global fight against pollution. We first propose based on the Pollution Haven Hypothesis (hereafter PHH) that the United States' strict regulations and institutional pressure for environmental performance might come at the expense of the environment in other countries due to U.S. firms' offshoring strategy. According to $\mathrm{PHH}$, "liberalized trade in goods will lead to the relocation of pollution intensive production from high income and stringent environmental regulation countries to low income and lax environmental regulation countries" (Taylor, 2005). For example, a recent study in China using atmospheric modeling found that 17-36 percent of four major anthropogenic air

pollutants (sulfur dioxide, nitric oxide, carbon monoxide, and black carbon) emitted in that country are associated with the production of goods for export, and that about 21 percent of export-related emissions are attributable to goods destined for the United States (Lin et al., 2014). Unfortunately, most prior research on PHH has relied on aggregate country-, state-, or industrylevel information (Antweiler, Copeland, \& Taylor, 2001; Grossman \& Krueger, 1995; Hanna, 2010; Levinson, 2010, 2009), which partly explains some contradictory results in this research. 
To our knowledge, very few papers (e.g., Dowell, Hart, \& Yeung, 2000) have studied the issue at the level of the firm, where production-pollution decisions are made.

Do firms lower their emissions in developed and highly regulated countries by offshoring production to poor and less regulated countries? Theoretically, firms can arbitrage between varying institutional demands. For example, firms can redesign their supply chain, shifting their domestic production to cleaner segments and importing from poor or low-wage countries (LWCs) products that are more polluting to produce, thereby achieving compliance and avoidance at the same time. LWCs have comparative advantage in labor costs, therefore they should attract more labor-intensive industries rather than the more polluting capital-intensive industries (Cole \& Elliott, 2005). However, the lax environmental standards and poor environmental regulatory quality in LWCs might influence firms' offshoring strategy to be based on environmental rather than pure labor-cost considerations (Esty \& Porter, 2002).

To test these ideas, we linked firm-level imports and plant-level production statistics maintained by the U.S. Census Bureau (Census) to plant-level toxics emissions information from the Environmental Protection Agency's (EPA's) Toxics Release Inventory (TRI) database. We found that domestic plants pollute less on American soil as their parent firm imports more from LWCs: When a plant's parent firm increases its share of imports from LWCs by 10 percentage points, the plant's toxic emissions on American soil fall by 4-6 percent. We then explored a few micro-mechanisms and uncovered evidence consistent with the PHH and a "pollution-offshoring" strategy. In particular, we found that goods imported by U.S. firms from LWCs are in more pollution-intensive industries than goods imported from the rest of the world, and U.S. plants shift their production to less pollution-intensive industries, produce less waste, and spend less on pollution abatement when their parent firm imports more from LWCs. Taken together, our evidence suggests that many U.S. firms are offshoring more pollution-intensive production to LWCs.

Despite its potential benefit, an institutional arbitrage strategy brings about multinational coordination costs and regulatory risks. Therefore, we investigate two sources of heterogeneity that would affect firms' pollution-offshoring strategy. The first source of heterogeneity is the local institution. Drawing insights from the social activism and environmental justice literature (Hiatt, Grandy, \& Lee, 2016; King, 2008; Mohai, Pellow, \& Roberts, 2009), we conjecture that American firms will engage in more pollution offshoring if their plants are located in counties 
where the local institutions can exert greater pressure on environmental performance, such as counties with a more informed (educated) population, a higher voter turnout in presidential elections, or a stronger presence of environmental nongovernment organizations (NGOs) like the Sierra Club. The second source of heterogeneity is firm capability. Drawing from the stakeholder and slack-resource arguments in the corporate social responsibility (CSR) literature (Berchicci, Dowell, \& King, 2012; Chin, Hambrick, \& Treviño, 2013; Dowell et al., 2000; Waddock \& Graves, 1997), we hypothesize that more-capable firms will enjoy greater compliance benefits and lower compliance costs; they will therefore have greater incentive to comply with strict environmental requirements in the United States and engage in less pollution offshoring. Our empirical results support these conjectures.

This paper makes a few contributions to the study of environmental strategy. It provides the first micro-level empirical evidence, based on the most comprehensive sample of U.S. manufacturing firms, that the "green shift" of U.S. manufacturing coincides with a "brown shift" of imports from poor countries. It advances the PHH by pointing out an important mechanism of strategic adjustment (e.g., product portfolio reconfiguration) within firms, which has not been previously distinguished from extensive-margin adjustments (e.g., firm entry and exit) at the industry or regional level. In addition, it highlights the impact of local institutions and firm capability on firms' environmental strategy. While the idea of institutional arbitrage is not new, existing studies have been limited to multinational corporations and non-CSR institutional constraints. We extend the research on the CSR-financial performance link by pointing out that firms may appear to have achieved both good CSR and good financial performance if their global CSR performance is not carefully evaluated. At the same time, we point out that a firm's capability influences the costs and benefits of embracing CSR initiatives in each country, and consequently its global environmental strategy.

Finally, our empirical findings lend further credence to policy makers' assertions that there should be more coordination between international trade and environmental agreements (Keller \& Levinson, 2002). With the recent public debates around re- or near-shoring vs. offshoring, the impact of CSR considerations on the configuration of global production networks becomes increasingly salient. Environmental problems are increasingly global: A recent study shows that pollution from China contributes to a significant portion of the sulfate concentrates found over the western United States (Lin et al., 2014). A global response, therefore, is needed. 


\section{THEORY DEVELOPMENT}

Institutions are humanly devised constraints that structure human interactions; they include formal rules as well as informal norms of behavior and conventions (North, 1990). Institutions can be both supportive and detrimental to organizations. On the one hand, strong institutions promote economic growth by providing good information and enforcing property rights (North 1990). On the other hand, institutions can be developed independent of efficiency and diffused through coercive, mimetic, and normative processes (DiMaggio \& Powell, 1983; Meyer \& Rowan, 1977). Institutions vary not only by their strength and benefits/costs to organizations, but also by time and space. This creates an opportunity for organizations to arbitrage. Globalization relaxes the local institutional constraints and enables firms to arbitrage across institutional boundaries. In this paper, we focus on arbitraging in different environmental standards across countries.

\section{Arbitraging between environmental standards}

Pollution is a negative externality. By partially privatizing its social costs, strict environmental standards raise firms' production costs, which should in turn discourage pollution-intensive production. However, the impact of strict environmental standards on U.S. firms has been controversial in policy and academic debates. Many argue that strict environmental standards in the United States weaken American firms' competitiveness in international markets, causing declining manufacturing productivity (Greenstone, List, \& Syverson, 2012), plant closures (Becker \& Henderson, 2000; Henderson, 1996), losses of American jobs (Greenstone, 2002), and falling wages for American workers (Walker, 2013). In order to lower compliance costs, firms can innovate products and processes (King \& Lenox, 2001; Porter \& Van der Linde, 1995) or practice greenwashing (Kim \& Lyon, 2015). These strategies, however, are constrained by firm capabilities (Barnett \& Salomon, 2012; Berchicci et al., 2012) or societal scrutiny (Marquis \& Toffel, 2014).

Another strategy is to arbitrage between different environmental requirements. For example, in response to the Clean Air Act Amendments, firms use air pollution abatement techniques to remove pollutants from the air, but release these pollutants into water bodies, landfills, or the 
ground (Greenstone, 2003). It has also been found that firms operating across multiple jurisdictions in the United States produce more total waste (King \& Shaver, 2001).

Globalization provides an additional dimension along which firms can arbitrage. Whereas the annual cost of complying with environmental standards in the Unites States amounts to hundreds of billions of dollars and more than 2 percent of GDP, most less developed countries spend only a fraction of 1 percent (Jaffe et al., 1995) and have not been able to adopt strict environmental standards for fear of hurting economic growth (The Economist, 1998). Such differences create a unique arbitrage opportunity for firms from rich countries. For example, U.S. firms invested more outside the United States when they expected their county to be subject to more stringent environmental regulations (Hanna, 2010). The concern over "job killing" environmental regulations in the United States is one major obstacle to trade agreements such as the North American Free Trade Agreement (NAFTA).

In sum, firms can make several strategic adjustments at their existing plants to reduce pollution. First, the plants can adopt pollution prevention practices such as operational and procedural as well as material and equipment changes (Harrington, Deltas, \& Khanna, 2014). Pollution prevention reduces the total produced waste and lowers pollution levels and treatment costs (Berchicci et al., 2012; Dutt \& King, 2014; King \& Lenox, 2002). In addition, plants can invest in pollution abatement and treatment (Shadbegian \& Becker, 2005). Both of these approaches are costly. Therefore, the plants might also resort to a pollution-offshoring strategy. Specifically, firms can redesign their supply chain to locate more-polluting production in LWCs to "avoid" U.S. pollution standards, while assigning their domestic plants to produce in cleaner segments to "comply" with the U.S. standards. Accordingly, we propose the following:

Hypothesis 1: A domestic (U.S.) plant will emit less pollution as its parent firm offshores more production to low-wage countries relative to non-low-wage countries.

\section{Local institutions and global response}

Firms are subject to national regulations as well as local informal institutional pressures. Powerful local news media and activists can exert significant impact on firms (Hiatt et al., 2016; King, 2008). For example, when Butler County, Pennsylvania, was identified by the EPA as among the dirtiest counties, local residents successfully pressured the state to restrict nitrate 
emissions of a major steel plant before the plant was allowed to release waste into the Connoquenessing Creek (Powers, 2013). Local residents can also engage in protests, civil suits, and letter-writing campaigns to impose operational costs such as legal fees and public relations expenses, to distract managerial attention, or to threaten the firm's reputation amongst its customers, employees, and shareholders (Eesley \& Lenox, 2006). After Calhoun County, Texas, was identified by the EPA as one of the dirtiest counties in America, local residents organized various awareness programs to inform the public about local pollution. Under public pressure, Alcoa had to commit to aggressive pollution reduction initiatives at two local plants (Powers, 2013).

Some counties are more tolerant of noncompliance, or are less able to mobilize opposition to noncompliance, than others. Noncomplying firms in these counties are therefore less likely to relocate elsewhere (including relocating out of the country). This dynamic contributes to environmental inequality, such as the discriminatory siting of toxic facilities in the United States (Mohai et al., 2009). Consistently, both anecdotal and empirical evidence has shown that U.S. counties with more informed (educated) population and with greater voter turnout in presidential elections have fewer toxic facilities located in them (Shapiro, 2005), and these counties are more likely to force firms to cut emissions or relocate production (Hoffman \& Ocasio, 2001; Maxwell, Lyon, \& Hackett, 2000). Another important player is non-government social movement organizations such as the Sierra Club, which can engage their members to frame and influence individual values and stakeholder understandings, thereby affecting firm decisions (Hiatt, 2010).

Compared with increasingly powerful state and county stakeholders in the United States, communities in LWCs have less power against their governments due to both a lack of information and a lack of property rights. They might also have different incentives, as their basic economic needs have yet to be met. This results in more lenient environmental standards and lighter local institutional pressure for environmental performance in LWCs. Therefore, firms with their American plants located in counties that are expected to react more aggressively to toxic emissions will be more likely to offshore to LWCs.

Hypothesis 2: The negative impact of offshoring to low-wage countries on domestic pollution will be stronger for domestic (U.S.) plants located in counties where the local institutions are more powerful. 


\section{Firm capability and pollution offshoring}

Despite the higher costs, firms that adopt strong environmental management have been found to enjoy greater accounting returns (Hart \& Ahuja, 1996; Nehrt, 1996) or higher financial returns (Dowell et al., 2000; Klassen \& McLaughlin, 1996) or both (King \& Lenox, 2002). This is because socially responsible firms can potentially deter stakeholder activism (Reinhardt, 1999), attract consumers (Casadesus-Masanell et al., 2009; Elfenbein \& McManus, 2010; Servaes \& Tamayo, 2013) and motivate productive employees (Flammer, 2015; Prendergast, 2007; Tonin \& Vlassopoulos, 2014), thereby enhancing shareholder value (Eccles, Ioannou, \& Serafeim, 2014).

Firms' incentive to arbitrage institutional differences depends on the costs and benefits of arbitrage relative to those of strict compliance. These costs and benefits are partly driven by firm capabilities. Whereas less-capable firms often find it costly or challenging to meet environmental standards, more-capable firms will find it relatively easy to remain profitable while achieving these standards. Because capabilities are firm-specific and difficult to trade between firms, they are likely to act as an isolation mechanism for firms' environmental strategy and performance.

Firm capabilities that could influence the costs or benefits of environmental compliance mainly include productive capability, technological capability, environmental capability, and marketing capability. Among them, productive, technological, and environmental capabilities mainly reduce the costs of compliance. For example, firms with more productive plants or R\&D intensive firms are more likely to be at the technological frontier and will find it less costly to innovate their products and processes; they are also more likely to have accumulated slack resources necessary to undertake CSR (Chin et al., 2013). For another example, manufacturing firms that have invested more in environmental technologies and developed more environmental capability are more effective at pollution prevention and therefore enjoy better environmental performance (Berchicci et al., 2012).

In contrast, marketing capability can increase the benefits from compliance. For example, firms with a greater brand equity for product innovation and quality are likely to enjoy a greater "stakeholder influencing capacity" and send a more credible signal by engaging in CSR than firms with less brand equity (Barnett, 2007; Dowell et al., 2000), thereby profiting more from compliance. Furthermore, these firms are more likely to compete based on product differentiation than on cost leadership; they therefore will be under less cost pressure when 
making environmental decisions. We therefore expect more capable firms to engage in less pollution offshoring.

Hypothesis 3: The negative impact of offshoring to low-wage countries on domestic pollution will be weaker for more capable plants and firms.

\section{THE U.S. ENVIRONMENT AND IMPORTS FROM LWCS}

The EPA's TRI program is the first large-scale initiative to track facility-level toxic pollution emissions in the United States. Introduced by the Emergency Planning and Community Right to Know Act in 1986, the TRI program intends to provide public environmental information and to affect firm behavior indirectly through consumer, public, or community pressure (Konar \& Cohen, 1997). ${ }^{1}$ The TRI database has also become one of the most widely accessed databases on environmental performance across facilities and over time. It has been used by a large body of stakeholders including the government, investors, potential employees, media, and the general public. Prior research shows that residential house prices in heavily polluted areas declined after the TRI database was published (Oberholzer-Gee \& Mitsunari, 2006). Both public media and the stock market responded negatively when a firm reported higher emissions in the TRI (Hamilton, 1995). Firms that had experienced the deepest stock price declines in response to their TRI reports subsequently reduced emissions more than their industry peers (Konar \& Cohen, 1997). In fact, plants that reported to TRI dropped their total pollutant emissions by about 60 percent between 1988 and 2005, leading the EPA to conclude that the "national publication of the TRI data by the government, followed by analysis by citizens' groups and the news media, led to action by industry to reduce emissions" (EPA, 2000; Oberholzer-Gee \& Mitsunari, 2006).

Based on TRI, we constructed an overview of the toxic emissions from U.S. manufacturing plants. Consistent with prior statistics (e.g., Levinson, 2009), Figure 1 in the Online Appendix

${ }^{1}$ The EPA requires facilities that emit more than 25,000 pounds or handle more than 10,000 pounds of any of the $600+$ designated toxic chemicals to self-report emissions in the TRI database. A few mechanisms are adopted to ensure its accuracy. First, EPA annually inspects both reporting facilities and non-reporting facilities that are in TRI industries. Violations, including late reporting, failure to report, or data quality issues, can lead to penalties of $\$ 25,000$ per day, per chemical, or per violation, and may be subject to criminal charges. Second, starting from 1995, EPA reduces or waives certain penalties for environmental violations that are voluntarily disclosed to the government. These enforcement mechanisms give firms incentive to self-report. 
shows that the emissions of major air pollutants by U.S. manufacturers fell by more than half between 1992 and 2009, despite the significant growth in real U.S. manufacturing output.

In comparison to Figure 1, we plotted the overall trends in imports in Figure 2 (see Online Appendix) based on Census' aggregate trade statistics. Figure 2 shows that while imports from LWCs have been small historically, they have increased substantially in recent years as trade barriers have been removed. Between 1992 and 2009, when the real value of total U.S. imports more than doubled, the real value of imports from LWCs grew more than ten-fold. Consequently, the share of total U.S. imports from LWCs in this period rose from 7 percent to about 23 percent. The increasing share of imports from LWCs in Figure 2 corresponds to the decreasing air pollution in Figure 1.

Figure 3 in the Online Appendix shows that between 1992 and 2009, industries that had a greater increase in the share of imports from LWCs also experienced a greater reduction in air pollutant emissions from U.S. plants. For example, industries that experienced the greatest increase in imports from LWCs were in the sectors of printing (Standard Industrial Classification (SIC) 278), apparel and textile (SICs 235 and 238), rubber and plastics (SIC302), and furniture (SICs 251, 254, and 259); all experienced some of the largest drops in air pollution emissions. In contrast, industries that had the least increase in imports from LWCs due to transportation costs or trade barriers, including industries in the sectors of food (SIC 208), stone, clay, and glass products (SIC 325), and tobacco products (SIC 214), experienced the least improvement in air pollution emissions. Together, Figures 1 through 3 suggest a potential substitution effect between imports from LWCs and domestic emissions at the national and industry levels.

\section{EMPIRICAL DESIGN}

We used manufacturing firms' imports from overseas to proxy for production offshoring. Our empirical tests combine firm-level trade (mostly of manufacturing products), plant-level production, and plant-level pollution data. This approach offers several benefits. First, it fills a gap in prior research about the impact of globalization on the environment, which is mostly at the country, state, and industry levels due to data limitation. Second, it allows us to control for multiple alternative explanations for environmental performance such as scale of production, capital intensity, skilled labor requirement, and pollution abatement at the plant level. Finally, it 
allows us to examine the impact of different local institutions and productivity on individual plants within the same firm.

\section{Samples, data sources, and variables}

We constructed our samples from several sources. Our first data source is the plant-level toxic emissions data published in the EPA's TRI database, which contains approximately 80,000 facility-chemical reports from more than 20,000 different plants. Toffel and Marshall (2004) compare 13 methods of aggregating chemical-specific release data to the plant level and recommend EPA's Risk-Screening Environmental Indicators (RSEI) model as the most comprehensive model for estimating the impacts of toxic releases on local residents' human health. The RSEI model estimates the toxicity weight for each chemical based on its toxicity, its fate and transport through the environment after its release, the route (inhalation and oral) and extent of human exposure, and its single most sensitive adverse effect (cancer and non-cancer) (EPA, 2012).

We used the TRI database and the RSEI model to construct several variables. The first variable, toxic emissions, gauges the total plant-level toxic emissions. We define toxic emissions from a plant as its all-media release of designated toxic chemicals, multiplied by the RSEI toxicity weight for each chemical; emissions to air are weighted using inhalation toxicity and emissions to other media are weighted using oral toxicity (Gamper-Rabindran, 2006). An alternative measure using the total toxicity-weighted emissions scaled by plant output generated similar results. The second group of variables is to measure the toxic content of a firm's imports. We summed the RSEI-based toxic emissions of all plants in each 4-digit SIC industry in 1992 and divided the sum by the total output from that industry in 1992, based on the NBER-CES Manufacturing Industry Database (Bartelsman \& Gray, 1996), to derive a pollution intensity measure for that industry. We then summed a firm's import value in each industry, weighted by the industry's pollution intensity, to derive the firm's toxic imports, which measures the toxic content of a firm's imports. We also scaled toxic imports using the firm's total imports to derive 
(toxic imports/total imports), which measures the pollution intensity of a firm's imports. ${ }^{2} \mathrm{We}$ constructed the third group of variables with a similar methodology: We summed a plant's output in each industry, weighted by the industry's pollution intensity, to derive the overall pollution content and intensity of a plant's output, toxic output and (toxic output/plant shipment), respectively. As a robustness check, we constructed alternative measures of toxic imports and toxic output using the World Bank's "Industrial Pollution Projection System” (IPPS); results were similar. Finally, we constructed two variables from TRI to capture plant-level operational efforts in reducing pollution. They include the number of pollution prevention (P2) practices (Harrington et al., 2014), and total tonnage of production waste.

Our second data source is plant-level micro data from the U.S. Census. It is used (1) to control for other factors that might influence pollution emissions, such as plant size (plant output), capital expenditures, and share of non-production workers over the entire workforce (skill intensity, which can also proxy for the plant's production technology), (2) to derive the overall pollution intensity of a plant's output, as mentioned in the previous paragraph, (3) to calculate the cost of fuel consumption per unit of output as a measure of energy efficiency that could potentially explain the change in plant-level pollution emissions, and (4) to measure plant capability (productivity). The Census micro data on manufacturing plants include the Census of Manufactures (CM) and the Annual Survey of Manufactures (ASM). CM data are collected during the economic census, which takes place in years ending in 2 and 7 and covers approximately 350,000 manufacturing plants each time. The ASM typically samples about 60,000 plants in non-census years. All plants with more than 250 employees and all plants of large firms are included by design. Some 40,000 other plants are selected with a probability proportional to a composite measure of their size. Once a plant is surveyed, the ASM continues surveying it to form a five-year panel. We linked the Census and TRI datasets using the existing bridge files maintained by the Census for 1992-1999 and by manual matching using plant names and addresses for subsequent years.

\footnotetext{
${ }^{2}$ Because information about industry-level pollution intensity in most exporting countries does not exist, using U.S. pollution intensity as a proxy for pollution intensity of imported goods is a common practice in the literature (Levinson, 2009). Such a measure assumes that the ordering of industries based on pollution intensity overseas is the same as in the US. For example, the primary metal industry is assumed to be more polluting per dollar of output than the food industry in both the U.S. and LWCs because the underlying technology is similar.
} 
Our third data source is the U.S. Census' Longitudinal Firm Trade Transaction Database (LFTTD). The database covers all transactions of goods that crossed U.S. borders. For each transaction, the database contains a firm identifier and pertinent details of the transaction as well as a 10-digit Harmonized System (HS) classification code of the product category. We followed Pierce and Schott (2012) by linking the HS codes to the 1987 version of four-digit SICs. To identify imports from LWCs, we relied on a list provided by Bernard et al. (2006), who classify a country as an LWC if its average annual GDP per capita was less than 5 percent of the U.S. annual GDP per capita in 1972-1992. A list of LWCs is provided in the Online Appendix. China, India, and most African countries are on the list. We calculated a firm's LWC import share as the percentage of its total imports that originated from LWCs.

Our fourth data source is the plant-level Pollution Abatement Costs and Expenditures (PACE) survey provided by U.S. Census, which is the most comprehensive survey of environmental abatement costs in the United States. Abatement costs include pollution prevention, pollution treatment, waste recycling, and disposal. We used the PACE surveys for the years when they are available in our sample period: 1992-1994, 1999, and 2005. We used total Pollution Abatement Operating Costs, which comprise salaries and wages, parts and materials, fuel and electricity, capital depreciation, contract work, equipment leasing, and additional operating costs associated with the abatement of air and water pollution as well as solid waste reduction or disposal.

Finally, we complemented our firm- and plant-level data with state-level Sierra Club membership information and county-level demographic information (college education and voter turnout) based on the U.S. Census' American Community Survey. We also matched parent firms that are publicly listed to the Compustat dataset in order to collect information about their $R \& D$ and brand equity (i.e., R\&D and advertising expenditure, see Morck \& Yeung, 1992).

Our main sample is the intersection of plants' pollution data from TRI, plants' operating information from ASM and CM, and firm's import importation from LFTTD. This sample contains about 18,000 plants of more than 8,000 U.S. parent firms for a total of 137,000 plantyear observations in 1992-2009. Table 1 provides summary statistics for this sample. An average importing firm sources 16 percent of its manufacturing imports from LWCs, slightly higher than the national average of 15 percent that we calculated based on Census' aggregate trade statistics. The skill intensity variable has a mean of 0.35 ; that is, non-production workers' salaries account for about 35 percent of an average plant's total salaries. The sample plants are relatively large: A 
typical plant has about 418 employees and manufactures a total value of $\$ 175$ million of output. A separate calculation reveals that plants in our sample accounted for more than 80 percent of all U.S. manufacturing plants' total toxic emissions in the sample period.

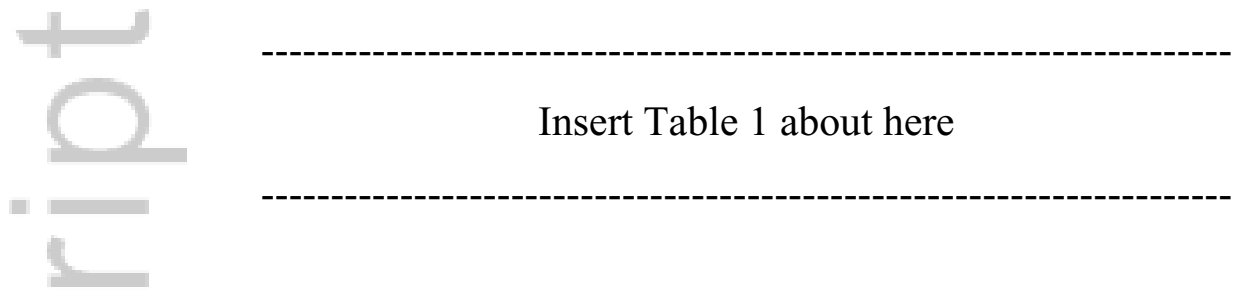

Table 1 also reports the pairwise correlation among our key variables of interest. It shows that a plant's toxic emission is negatively correlated with its parent firm's share of imports from LWCs, but positively related to the plant's size, capital expenditures, and total volume of imports. These simple correlation statistics foreshadow our subsequent multivariate regression results.

\section{Specifications}

We mainly used the following specification to estimate toxic emissions at the plant level:

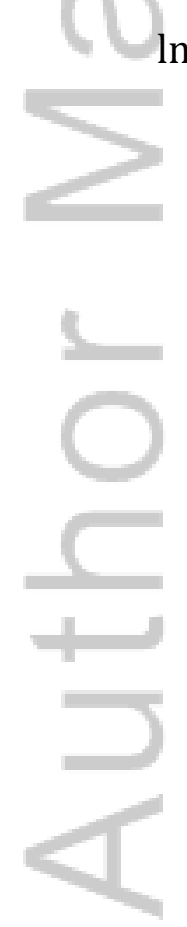

This article is protected by copyright. All rights reserved. 
Table 2 reports our main results based on Equation 1. All columns include plant fixed effects. In addition, columns (1) and (6) include year fixed effects, and columns (2)-(5) include industry*year fixed effects to control for changes in industry-specific technology and reductions in trade costs over time. Coefficients on the control variables are consistent with our expectation. In general, larger plants, plants with larger capital expenditures, and plants with a larger proportion of production workers tended to produce greater toxic emissions. It is interesting to observe that total imports did not have a statistically significant impact on toxic emissions and including it did not qualitatively change the coefficients of LWC import share.

Insert Table 2 about here

The coefficient of -0.401 in column (2) implies that a 10 percentage-point increase in a plant's parent firm's LWC import share is correlated with about 4 percent reduction in the plant's toxic emissions. $\mathrm{H} 1$ is supported. We expect domestic firms to save significant environmental costs from this reduction in emissions. These costs include potential government fines, customer boycott, investments in equipment, pollution prevention, and recycling, as well as abatement costs. For abatement costs alone, Hartman, Wheeler, and Singh (1997) estimate the average abatements costs to be approximately $\$ 1,240$ (in 1993 dollars) per ton across manufacturing sectors. In our sample, the median plant emits about 8.1 thousand tons of toxic pollutants. In this case, a 4 percent reduction in toxic emission would have saved the plant 402 $(=1240 * 8.1 * 0.04)$ thousand dollars in abatement cots.

At the national level, over the 18-year sample period, we calculated based on the LFTTD and TRI databases that the share of imports from LWCs grew by 16 percentage points in the United States, and toxic emissions dropped by about 60 percent over similar period. Therefore, our results imply that, importing from LWCs over the sample period reduced U.S. plants' toxic emissions by $6.4(=16 * 4 / 10)$ percent, or around $10(=6.4 / 60)$ percent of the total drop in U.S. toxic emissions during this period. 
Robustness checks. One might wonder how much of the pollution-import effect is caused by imports from China. Results in column (3) suggest that imports from China indeed played a significant role, whereas imports from EU countries did not have a significant impact. That said, column (4) suggests that even after excluding China, LWC imports had a significant, albeit weaker, correlation with domestic pollution at the plant level. We also estimated column (2) on the two subsample periods before and after 2001, when China joined the WTO. Our main results held in both periods. We also ran a robustness check replacing imports from LWCs with imports from the "most polluting countries" based on countries' CO2 emission per GDP using the World Development Indicators; results are consistent. ${ }^{3}$

In column (5) we used an alternative measure of toxic emission following King and Lenox (2000). The alternative measure weights each chemical by its toxicity using the Reportable Quantities (RQ) provided by the EPA in the Comprehensive Environmental Response, Compensation, and Liability Act. RQ serves as a threshold for reporting accidental spills, therefore the toxicity weight for each chemical is calculated as the inverse of its RQ. The coefficients in column (5) show that our main findings hold with this alternative measure of emissions. We also scaled the dependent variables by the plant output and lagged the independent variables; results are similar.

Endogeneity. Despite our efforts to control for determinants of pollution, there could be some unobservable variables that bias our estimates. Two obvious candidates for such unobservable factors are regulation and technology. Firms may be reducing pollution in the United States due to more strict environmental regulations or because they have developed new technologies to reduce pollution; at the same time, they may be increasing imports from LWCs

\footnotetext{
${ }^{3}$ In order to identify countries with lax environmental standards independent of economic development or wage level, we first constructed a list of "most polluting countries" (MPCs). We ranked countries by their annual carbon dioxide (CO2) emission (kilograms per inflation-adjusted GDP), one of the World Development Indicators (WorldBank, 2010) that have been used in prior studies (Levinson, 2009) to proxy the strength of environmental regulation across countries. We chose the minimum level of $\mathrm{CO} 2$ emissions by the top-tercile countries, 1 kilogram per dollar GDP, as the threshold. A country is categorized as an MPC if its 1992-2009 average CO2 emissions exceeded 1 kilogram per GDP. A few MPCs from Eastern Europe and the Middle East (presumably fossil fuel burners) stand out as different from LWCs.
} 
due to increased U.S. demand for LWC products. These unobservable factors might affect a firm's decision to import and emit and thus induce a correlation between the right-hand-side variables and the error term.

To address the problem of omitted variables, we first used a longitudinal, rather than crosssectional, analysis based on a panel of plant-level dataset. In addition, we included plant and industry-year fixed effects to account for unobservable time-invariant factors at the plant-level (such as plant innovativeness and technological capability) and industry-specific yearly events that would affect pollution (such as industry-specific regulatory change, technological progress, or tariff changes). Furthermore, we adopted an instrumental-variable (IV) strategy.

We instrumented for the firm-level share of imports from LWCs using the industry-level contemporaneous Chinese exports to eight non-U.S. Organization for Economic Co-operation and Development (OECD) countries, following the method in Autor, Dorn, and Hanson (2013). A significant proportion of the growth in LWC exports over our sample period was driven by Chinese exports. China's transition to a market-oriented economy, including lowering trade barriers, an abundant supply of labor released from urbanization, comprehensive policy reforms, and accession to the WTO, contributed to a substantial increase in China's manufacturing competitiveness. We therefore expect industries that experienced exports from China to non-U.S. OECD countries to have also experienced more imports from LWCs in the United States. However, the increase in exports from China to non-U.S. OECD countries mainly reflects a "supply shock" driven by China's manufacturing competitiveness. It is therefore less likely to be correlated with demand-side shocks in the United States or U.S. regulation and technology.

We use data from the United Nation Comrade Database on imports to construct the IV as follows:

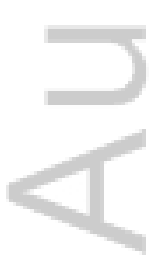

$$
\begin{aligned}
L W C \text { Share }_{i t} & =\sum j \frac{I_{i j t}}{I_{i t}} \frac{\overline{L W C}_{J t}}{I_{J t}} \#(5) \\
\frac{\widetilde{L W C_{J t}}}{I_{J t}} & =\frac{I_{o c j t}}{I_{o j t}} \#(6),
\end{aligned}
$$

where $I_{i j t}$ is the value of imports by firm $i$ in industry $j$ at year $t$ and $I_{i t}$ is the value of imports by firm $i$ at year $t$. $I_{o c j t}$ is imports in the eight non-U.S. OECD countries from China in industry $j$ 
and year $t . I_{o j t}$ is total imports in the eight non-U.S. OECD countries from all countries in industry $j$ and year $t$. We report the two-stage least square (2SLS) results using the IV in column (6) of Table 2. The coefficients are consistent with those in column (1).

Mechanisms. While Table 2 suggests that imports from LWCs reduced U.S. plants' pollution emissions, it does not prove a substitution effect between pollution in the United States and pollution in LWCs. A few mechanisms can be at play. We explore these mechanisms in the next few paragraphs.

First, it could be that as U.S. firms import cheaper products from LWCs, their costs decrease and profit increase. The increased profits would enable U.S. firms to finance more environmental projects. If this were the case, we should see U.S. plants spend more on pollution abatement as their parent firm imports more from LWCs. To test this mechanism, we estimated in the first two columns of Table 3 the correlation between imports from LWCs and U.S. plants' expenditures on pollution abatement. Because of the significant gaps in time coverage of PACE data, we had to use industry*year and plant fixed effects separately but not jointly. In addition to total abatement costs, we also estimated abatement costs divided by a plant's total output; results were similar. The results refute the mechanism of cheap LWC production resulting in more U.S. investments in pollution abatement, thereby reducing plant-level pollution emissions. Instead, Columns (1)-(2) in Table 3 show that domestic plants spent less on pollution abatement when their parent firm imported more from LWCs. The coefficient of -0.314 implies that a 10 percentage-point increase in a plant's parent firm's LWC import share reduced a plant's pollution abatement costs by about 3.14 percent, or about 22,100 nominal dollars, relative to about $\$ 704,000$ spent on abatement by an average plant in our sample.

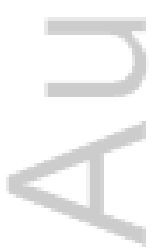

Insert Table 3 about here

Following a similar logic, we investigated whether plants increased pollution prevention (P2) practices as their parent firm imported more from LWCs. Prior studies have shown that P2 practices reduce toxic emissions (Harrington et al., 2014). Our results in Column (3) show that 
plants did not significantly step up their P2 practices as their parent firm imported more from LWCs.

Our main dependent variable is based on emissions, which roughly equate the amount of pollution produced minus the amount of pollution treated and recycled. Therefore, rather than offshoring, plants can reduce emissions through pollution prevention and/or waste treatment (Dutt \& King, 2014; King \& Lenox, 2002). Pollution prevention reduces the total produced waste, thereby lowering pollution levels and treatment costs (Berchicci et al., 2012). In order to further investigate these mechanisms, we estimated the total amount of produced waste in Column (4). The results show that plants indeed reduced their production waste as their parent imported more from LWCs. Consistently, Column (5) shows that the plants also consumed less fuel, controlling for total output. Because the reduction in production waste and fuel consumption can be caused by either pollution prevention (without pollution offshoring) or pollution offshoring, and Column (3) shows that plants did not significantly increased pollution prevention, we concluded that the reduction in produced waste and fuel consumption was mainly caused by pollution offshoring.

Next, we tested the pollution-offshoring strategy at the firm level: firms moving highemission production offshore to concentrate domestic production on less-polluting goods and processes. To test this mechanism, we first checked if imports from LWCs were more pollution intensive. The coefficients in Table 4 show that the pollution content of a firm's imports was positively and significantly related to its LWC import share. Coefficients in column (2) imply that a 10-percentage-point increase in a firm's LWC import share is associated with a 2.5 percent increase in the amount of its "toxic imports." Coefficients in columns (3) and (4) imply that a 10percentage-point increase in a firm's LWC import share is associated with an increase in the pollution intensity of its imports of about 0.10 , or approximately 20 percent of the sample's median value of pollution intensity of imports.

Insert Table 4 about here 
Pollution offshoring at the firm level means that either (1) firm changed their plant mix, establishing new plants in cleaner industries and closing down plants in dirtier industries, or (2) plants changed their product mix, increasing production in cleaner industries and reducing production in dirtier industries. We focused on (2) for two reasons. First, our supplementary analyses did not return strong support for (1), partly due to lack of information on exited plants. Second, plant closure and establishment would not have explained our plant-level finding in Table 2. We therefore investigated in Table 5 if plants increased their output in cleaner segments relative to their output in dirtier segments as their parent imported more from LWCs. The coefficients imply that a 10-percentage-point increase in the share of imports from LWCs lowered the toxicity-weighted output of a U.S. plant by about 0.3 percent.

\section{Insert Table 5 about here}

Together, Tables 2-5 provide robust evidence of "pollution offshoring" by U.S. firms. They imported products in more pollution-intensive industries from LWCs than from rich countries. Correspondingly, U.S. plants polluted less on U.S. soil, produced less waste, and spent less on pollution abatement, and produced more in less-polluting industries.

\section{Local institutions}

Table 6 tests the impact of local institutions. We expanded Equation 1 by adding measures of local institutional power in the area where a plant is located and their interactions with LWC import share. Results suggest that the negative impact of imports from LWCs on U.S. plants' pollution emission was stronger for plants located in counties with a more educated population, counties with stronger voter turnout, and states with a greater membership in Sierra Club. In fact, a significant portion of the negative impact of imports from LWCs on domestic pollution seems to be driven by the power of local institutions. $\mathrm{H} 2$ is supported.

Insert Table 6 about here 


\section{Firm capability}

Table 7 adds measures of plant and firm capability. In order to present the full model, all columns include one measure of local institutional pressure on environmental performance, Sierra Club membership, and its interaction with LWC import share. Coefficients to these variables are similar to those in Table 6, Column (1), albeit economically larger. Coefficients to the capability measures suggest that more productive plants and plants of parent firms investing more in R\&D and brand equity pollute less. In addition, the negative impact of imports from LWCs on pollution is weaker for more capable plants (e.g., more productive plants, plants of more productive parent firms, and plants of parent firms that invest more in R\&D and brand equity). H3 is supported.

\section{Insert Table 7 about here}

In sum, results in Tables 2-7 suggest a potential substitution between pollution-intensive production in the United States and such production offshored to LWCs, and these effects are stronger for U.S. plants located in counties where local institutions are more powerful but weaker for more-capable U.S. firms.

\section{DISCUSSION AND CONCLUSIONS}

This paper investigates firms' production offshoring strategy and their domestic toxic emissions. Our empirical results suggest that domestic (U.S.) plants released less toxic emission when their parent firm imported more from LWCs. In addition, goods imported by U.S. firms from LWCs were in more pollution-intensive industries. U.S. plants also shifted production to less pollutionintensive industries, produced less waste, and spent less on pollution abatement when their parent firm imported more from LWCs. The negative impact of imports from LWCs on domestic plants' toxic emissions was stronger for plants located in counties where the local institutions can exert more powerful pressure on environmental performance, but weaker for more capable firms 
and plants. These results support the Pollution Haven Hypothesis and highlight the role of local institutions and firm capability in explaining firms' choice of offshoring and environmental strategy.

This paper's main contribution is to introduce the role of firm strategy to the policy debate about global coordination to combat environmental problems. It advances the Pollution Haven Hypothesis by pointing out an important mechanism of strategic adjustments at the firm level. It provides the first micro-level empirical evidence of "pollution offshoring" and calls for more coordination between international trade and environmental agreements. In addition, it highlights the role of local institutions and firm capabilities in explaining firms' choice of offshoring and environmental strategy.

One intriguing question our results raise is how firms "get away with" offshoring pollution. We therefore ran a few supplementary analyses to explore any further heterogeneity across firms that would influence the relationship between imports from LWCs and domestic pollution. First, Dowell et al. (2000) find that U.S. multinational corporations (MNCs) adopting a single stringent global environmental standard enjoy higher market values in the U.S. stock market. We would expect these U.S. MNCs to pursue less pollution-offshoring. Unfortunately we do not have information about which U.S. MNCs adopted a single stringent global environmental standard during our sample period. As a supplementary analysis, we included an MNC dummy in our regression. We did not find a significant difference between MNCs and domestic firms. Our results may be different from those in Dowell et al. (2000) for a number of reasons in addition to the lack of comparable information about firms' internal environmental standards. First, we used different samples. Whereas Dowell et al.'s used a sample of large and public S\&P 500 MNCs for 1994-1997, we used a more comprehensive sample of more than 8,000 firms and 18,000 plants of all sizes and ownership for 1992-2009. Second, we used different econometric models. While Dowell et al. (2000) used both cross-sectional and random-effects models to allow for selection as part of their theory that countries with lax environmental regulations might attract poorer quality and less competitive firms, we used models with firm or plant fixed effects, industry-year effects, and an instrumental variable approach to alleviate endogeneity concerns, in order to test our theory. Whether U.S. firms adopting a single stringent global environmental standard pursue less pollution-offshoring can be an interesting subject for future research when data on more firms' international environmental standards become available. 
Consumers may be less sensitive to environmental issues in upstream production than environmental issues in downstream production. In a second supplementary analysis we explored if firms in downstream (less pollution-intensive) industries might procure more upstream (more pollution-intensive) products from LWCs. We first checked the relationship between a country's level of development and the "upstreamness" of its industries. Antràs et al. (2012) constructed a measure of industry upstreamness (or average distance from final use) and showed that a country's per capita GDP is not statistically related to the upstreamness of its exports. We then performed an industry-level, cross-sectional regression and found that the industry upstreamness is not statistically correlated with our measure of pollution intensity. For example, both the automobile and footwear industries are among the five most downstream industries, but automobile manufacturing is very polluting while footwear manufacturing is much less so. Finally, we reran our regressions to account for imports in firms' main and upstream segments, respectively. The results indicate no significantly different effects between imports in the main and upstream segments.

In a third supplementary analysis, we examined whether firms that are more visible to their customers might find it more difficult to engage in "pollution offshoring" without being caught, and will therefore have less incentive to do so. We investigated the impact of brand equity on pollution offshoring. We measured brand equity using advertising expenditure at both the industry and firm level. Our results are not presented here due to space limitations. They showed that for firms in industries with higher brand equity, and firms with higher brand equity themselves, imports from LWCs had a less negative impact on plants' toxic emissions. After controlling for brand equity, however, the negative impact of imports from LWCs on pollution is very similar to that in our main regressions.

It is worth emphasizing that we are not claiming nefarious activities by U.S. firms: They might just be optimizing and rebalancing their global sourcing network in response to increased costs for domestic environmental compliance. Alternatively, as more U.S. firms exit pollutionintensive industries, products in these industries might become more expensive, causing higher production costs for U.S. firms in the downstream industries. As a robustness check, we included the costs of the plant's material inputs in our regressions; results were similar.

It is worth clarifying that when adopting a pollution offshoring strategy, U.S. firms have not broken any environmental laws in either the United States or their host country. LWCs often care 
too much about maintaining exports and foreign direct investment to drive their economic growth to enforce strict environment regulation. For example, until very recently India strongly objected to a global climate-change accord, claiming that "developing countries should not be asked to limit their economic growth as a way of fixing a problem that was largely created by the others." India has also been reluctant to transit from fossil fuel to cleaner energy without significant financial commitment from the rich world (The New York Times, 2015). When U.S. firms are in compliance with both U.S. and foreign environmental regulations, it is not easy to detect that they follow less stringent environmental standards in the host country than in the United States. Besides, U.S. firms may adopt an internal practice for their overseas plants that is less strict than U.S. laws but stricter than the laws in the developing country, which may make the host-country residents less critical or even appreciative of U.S. firms' practices.

Still, to the extent that U.S. firms have a choice between the cheaper, pollution-intensive goods from LWCs and the more expensive goods produced by domestic suppliers under stringent environmental standards, they are making a strategic decision about the private costs of production vs. the public (and international) costs of pollution. Unfortunately, it is not always easy to correct environmental or labor malpractice by even the most famous MNCs in foreign countries. It took Nike almost a decade after the first report of its malpractices to announce that it would raise the minimum wage, significantly increase monitoring, adopt U.S. Occupational Safety and Health Administration clean air standards in all factories, and create the NGO Fair Labor Association (Business Insider, 2013). Foxconn, the Apple supplier that "has faced a firestorm of international media attention over its labor practices in China" and "reportedly improved working conditions there," has diversified into other low-wage nations: Malaysia, Mexico, Brazil, Vietnam, Indonesia, where labor regulations are more lax (Christian Science Monitor, 2012). With global environment and labor issues still in hot debate at the policy level, it is hard to blame individual firms - a situation that begs for policy and regulatory change at a higher level. More capable firms should actively engage in these policy debates in order to induce a regulatory framework that rewards firms that differentiate through CSR.

This paper has a few limitations that suggest opportunities for future study. First, we do not directly test the net impact of globalization on the environment in LWCs. On the one hand, offshoring by U.S. firms in more pollution-intensive industries can increase the size of pollutionintensive production in LWCs, exacerbating the pollution problem. On the other hand, offshoring 
by U.S. firms might bring to LWCs more advanced environmental technologies relative to what LWCs would have used without globalization, thereby causing less pollution for the same magnitude of production. A more comprehensive analysis of the impact of globalization on the environment in LWCs can be pursued when such data become available.

In addition, our main analyses do not differentiate between in-house offshoring and global outsourcing. More than 80 percent of jobs in labor-intensive industries such as textiles were outsourced, avoiding labor and environmental regulations, and hence offering lower costs (Christian Science Monitor, 2012). Apple employs 60,000 staff but relies on an additional 700,000 people by subcontracting its production (New York Times, 2012). On the one hand, offshoring pollution-intensive production to firms' own subsidiaries in LWCs provides better control by the U.S. parent firm and enables the overseas subsidiaries to self-regulate in accordance with their internal standards (Dowell et al., 2000). On the other hand, subcontracting pollution-intensive production to independent contractors helps insulate firms from the potential liabilities and reputational damage in cases where something goes wrong. In order to shed light on these opposing theoretical expectations, we explored differences between imports from related parties (foreign subsidiaries or affiliates of MNCs) and imports from independent third parties. Imports are categorized in the LFTTD database as being from related parties if the importer owns, controls, or holds voting power equivalent to at least 6 percent of the outstanding voting shares of the exporter. Our results suggest that firms' imports from related parties in LWCs do not have a statistically different correlation with domestic emissions than firms' imports from independent parties in LWCs. On average, in our sample, the imports from related parties in LWCs accounted for less than 1 percent of a firm's total imports. Therefore, the economic significance of importing from related parties in LWCs remains small; the environmental effects of importing from LWCs are primarily driven by imports from arm's length transactions with unrelated parties.

In sum, this paper highlights the relationship between firms' offshoring strategy and their environmental performance in the United States. In addition to the theoretical contributions highlighted herein, the paper provides plant-level, empirical evidence of offshoring, pollution, abatement, and product-mix adjustments using a unique data set of a large sample of U.S. firms and plants. It will, we hope, encourage more empirical studies to complement both the extensive 
efforts in the literature on global manufacturing and environmental strategies and the heated policy debates on the sustainability of globalization.

Acknowledgements: The research in this paper was conducted while both authors were Special

Sworn Status researchers of the U.S. Census Bureau at the Michigan Census Research Data Center (MCRDC). Support for this research at the MCRDC from the National Science Foundation NSF (ITR-0427889) is gratefully acknowledged. Any opinions and conclusions expressed herein are those of the author(s) and do not necessarily represent the views of the U.S. Census Bureau. All results have been reviewed to ensure that no confidential information is disclosed. We thank Gautam Ahuja, Eun-Hee Kim, Francine Lafontaine, Arik Levinson, Tom Lyon, Nick Powers, Jordan Siegel, Jagadeesh Sivadasan, Reed Walker, Jim Westphal, Nathan Wilson, seminar participants at University of Michigan, Academy of Management, and Society for Institutional \& Organizational Economics for helpful comments. We also thank Randy Becker for information about the PACE surveys, and Luca Berchicc, Nilanjana Dutt, and Andrew King for the RQ measure.

\section{REFERENCES}

Antràs P, Chor D, Fally T, Hillberry R. 2012. Measuring the Upstreamness of Production and Trade Flows. (3): 412-416.

Antweiler W, Copeland BR, Taylor MS. 2001. Is Free Trade Good for the Environment? (4): 877-908.

Autor DH, Dorn D, Hanson GH. 2013. The China Syndrome: Local Labor Market Effects of Import Competition in the United States.

Barnett ML. 2007. Stakeholder influence capacity and the variability of financial returns to corporate social responsibility. (3): 794-816.

Barnett ML, Salomon RM. 2012. Does it pay to be really good? addressing the shape of the relationship between social and financial performance.

(11): 1304-1320.

Bartelsman EJ, Gray W. 1996. The NBER Manufacturing Productivity Database.

Becker RA, Henderson JV. 2000. Effects of Air Quality Regulations on Polluting Industries. (2): 379-421.

Berchicci L, Dowell G, King AA. 2012. Environmental capabilities and corporate strategy: exploring acquisitions among U.S. manufacturing firms.

(9): 1053-1071.

Bernard AB, Jensen JB, Schott PK. 2006. Survival of the best fit: Exposure to low-wage countries and the (uneven) growth of U.S. manufacturing plants.

(1): 219-237.

Business Insider. 2013. How Nike Solved Its Sweatshop Problem. 
Casadesus-Masanell R, Crooke M, Reinhardt F, Vasishth V. 2009. Households' Willingness to Pay for "Green" Goods: Evidence from Patagonia's Introduction of Organic Cotton Sportswear.

(1): 203-233.

Chay KY, Greenstone M. 2003. The Impact of Air Pollution on Infant Mortality: Evidence from Geographic Variation in Pollution Shocks Induced by a Recession.

(3): 1121-1167.

Chin MK, Hambrick DC, Treviño LK. 2013. Political Ideologies of CEOs: The Influence of Executives' Values on Corporate Social Responsibility.

(2): 197-232.

Christian Science Monitor. 2012. Foxconn Moves into Indonesia, Worrying Labor Groups.

Cole MA, Elliott RJR. 2005. FDI and the Capital Intensity of "Dirty" Sectors: A Missing Piece of the Pollution Haven Puzzle.

(4): 530-548.

DiMaggio PJ, Powell WW. 1983. The iron cage revisited: institutional isomorphism and collective rationality in organizational fields.

: 147-160.

Dowell G, Hart S, Yeung B. 2000. Do Corporate Global Environmental Standards Create or Destroy

Market Value?

(8): 1059-1074.

Dutt N, King AA. 2014. The Judgment of Garbage: End-of-Pipe Treatment and Waste Reduction.

(7): 1812-1828.

Eccles RG, loannou I, Serafeim G. 2014. The Impact of Corporate Sustainability on Organizational

Processes and Performance.

(11): 2835-2857.

Eesley C, Lenox MJ. 2006. Firm responses to secondary stakeholder action.

(8): 765-781.

Elfenbein DW, McManus B. 2010. A Greater Price for a Greater Good? Evidence That Consumers Pay More for Charity-Linked Products.

(2): 28-60.

EPA. 2000. Assessment of the incentives created by public disclosure of off-site consequence analysis information for reduction in the risk of accidental releases, Environmental Protection Agency:

Washington D.C.

EPA. 2012. EPA's Risk-Screening Environmental Indicators (RSEI) Methodology.

Esty DC, Porter ME. 2002. National environmental performance measurement and determinants. In

Oxford University Press: New York.

Esty D, Cornelius P (eds.),

Financial Times. 2015. India and France launch \$1tn solar power tie-up.

Flammer C. 2015. Does Corporate Social Responsibility Lead to Superior Financial Performance? A

Regression Discontinuity Approach.

(11): 2549-2568.

Gamper-Rabindran S. 2006. Did the EPA's voluntary industrial toxics program reduce emissions? A GIS analysis of distributional impacts and by-media analysis of substitution.

(1): 391-410.

Greenstone M. 2002. The Impacts of Environmental Regulations on Industrial Activity: Evidence from the 1970 and 1977 Clean Air Act Amendments and the Census of Manufactures.

(6): 1175-1219.

Greenstone M. 2003. Estimating Regulation-Induced Substitution: The Effect of the Clean Air Act on

Water and Ground.

(2).

Greenstone M, List JA, Syverson C. 2012. The Effects of Environmental Regulation on the

Competitiveness of U.S. Manufacturing.

Grossman GM, Krueger AB. 1995. Economic growth and the environment.

: 353-377.

Hamilton JT. 1995. Pollution as News: Media and Stock Market Reactions to the Toxics Release Inventory Data.

(1): 98-113.

This article is protected by copyright. All rights reserved. 
Hanna R. 2010. U.S. Environmental Regulation and FDI: Evidence from a Panel of US-Based Multinational Firms. (3): 158-189.

Harrington DR, Deltas G, Khanna M. 2014. Does Pollution Prevention Reduce Toxic Releases? A Dynamic Panel Model.

(2): 199-221.

Hart SL, Ahuja G. 1996. Does It Pay to Be Green? An Empirical Examination of the Relationship Between Emissions Reduction and Firm Performance.

(1): 30-37.

Hartman RS, Wheeler D, Singh M. 1997. The cost of air pollution abatement.

759-774.

Henderson JV. 1996. Effects of Air Quality Regulation.

Hiatt S. 2010. Institutional Actors and Entrepreneurial Choices: New Ventures in the Biodiesel Fuel Industry.

Hiatt S, Grandy J, Lee BH. 2016. Organizational Responses to Public and Private Politics: An Analysis of $\begin{array}{ll}\text { Climate Change Activists and U.S. Oil and Gas Firms. } & \text { (6): 1769-1786. }\end{array}$

Hoffman AJ, Ocasio W. 2001. Not All Events Are Attended Equally: Toward a Middle-Range Theory of Industry Attention to External Events.

(4): 414-434.

Jaffe AB, Peterson SR, Portney PR, Stavins RN. 1995. Environmental Regulation and the Competitiveness of U.S. Manufacturing: What Does the Evidence Tell Us?

(1): 132-163.

Keller W, Levinson A. 2002. Pollution Abatement Costs and Foreign Direct Investment Inflows to U.S.

States.

(4): 691-703.

Kim E-H, Lyon TP. 2015. Greenwash vs. Brownwash: Exaggeration and Undue Modesty in Corporate Sustainability Disclosure.

(3): 705-723.

King AA, Lenox MJ. 2000. Industry Self-Regulation Without Sanctions: The Chemical Industry's

$\begin{array}{ll}\text { Responsible Care Program. } & \text { (4): 698-716. }\end{array}$

King AA, Lenox MJ. 2001. LEAN AND GREEN? AN EMPIRICAL EXAMINATION OF THE RELATIONSHIP BETWEEN LEAN PRODUCTION AND ENVIRONMENTAL PERFORMANCE.

(3): 244-257.

King AA, Lenox MJ. 2002. Exploring the Locus of Profitable Pollution Reduction.

(2): 289-299.

King AA, Shaver JM. 2001. Are aliens green? Assessing foreign establishments' environmental conduct in the United states.

(11): 1069-1085.

King BG. 2008. A Political Mediation Model of Corporate Response to Social Movement Activism.

(3): 395-421.

Klassen RD, McLaughlin CP. 1996. The Impact of Environmental Management on Firm Performance.

(8): 1199-1214.

Konar S, Cohen MA. 1997. Information As Regulation: The Effect of Community Right to Know Laws on

Toxic Emissions.

(1): 109-124.

Levinson A. 2009. Technology, International Trade, and Pollution from U.S. Manufacturing.

(5): 2177-2192.

Levinson A. 2010. Offshoring Pollution: Is the United States Increasingly Importing Polluting Goods?

(1): 63-83.

Lin J, Pan D, Davis SJ, Zhang Q, He K, Wang C, Streets DG, Wuebbles DJ, Guan D. 2014. China's

international trade and air pollution in the United States. $\quad$ (5): 1736-1741.

Marquis C, Toffel MW. 2014. Scrutiny, Norms, and Selective Disclosure: A Global Study of Greenwashing.

Maxwell John WM, Lyon Thomas PL, Hackett Steven CH. 2000. Self - Regulation and Social Welfare: The Political Economy of Corporate Environmentalism.

(2): 583-618.

Meyer JW, Rowan B. 1977. Institutionalized Organizations: Formal Structure as Myth and Ceremony.

(2): 340-363.

This article is protected by copyright. All rights reserved. 
Mohai P, Pellow D, Roberts JT. 2009. Environmental Justice.

(1): 405-430.

Morck R, Yeung B. 1992. Internalization : An event study test.

41-56.

Nehrt C. 1996. Timing and Intensity Effects of Environmental Investments.

(7): 535-547.

New York Times. 2012. How the U.S. Lost Out on iPhone Work.

North DC. 1990.

. Cambridge University

Press: New York.

NPR. 2015. Nearly 200 Nations Adopt Climate Agreement At COP21 Talks In Paris.

Oberholzer-Gee F, Mitsunari M. 2006. Information regulation: Do the victims of externalities pay

attention?

(2): 141-158.

Pierce JR, Schott PK. 2012. A Concordance Between Ten-Digit U.S. Harmonized System Codes and

$\mathrm{SIC} /$ NAICS Product Classes and Industries.

: 61-96.

Porter ME, Van der Linde C. 1995. Toward a New Conception of the Environment-Competitiveness

Relationship.

(4): 97-118.

Powers N. 2013. Measuring the Impact of the Toxics Release Inventory: Evidence from Manufacturing Plant Births.

Prendergast C. 2007. The Motivation and Bias of Bureaucrats.

(1): 180-196.

Reinhardt F. 1999. Market Failure and the Environmental Policies of Firms: Economic Rationales for

"Beyond Compliance" Behavior.

(1): 9-21.

Servaes H, Tamayo A. 2013. The Impact of Corporate Social Responsibility on Firm Value: The Role of

Customer Awareness. $\quad$ (5): 1045-1061.

Shadbegian R, Becker R. 2005. A Change of PACE: Comparing the 1994 and 1999 Pollution Abatement

Costs and Expenditures Surveys.

(1): 63-95.

Shapiro J, Walker R. 2014. Why is the United States' Air Quality Improving? The Roles of Trade, Regulation, Productivity, and Preferences.

Shapiro MD. 2005. Equity and information: Information regulation, environmental justice, and risks from toxic chemicals.

(2): 373-398

Taylor MS. 2005. Unbundling the Pollution Haven Hypothesis.

(2).

The Economist. 1998. Dirt poor. In

The New York Times. 2015. Citing Urgency, World Leaders Converge on France for Climate Talks.

The White House. 2014. U.S.-China Joint Announcement on Climate Change.

Toffel MW, Marshall JD. 2004. Improving Environmental Performance Assessment: Comparative Analysis of Weighting Methods used to Evaluate Chemical Release Inventories.

(1-

2): $143-172$.

Tonin M, Vlassopoulos M. 2014. Corporate Philanthropy and Productivity: Evidence from an Online Real

Effort Experiment.

(8): 1795-1811.

Waddock SA, Graves SB. 1997. The Corporate Social Performance-Financial performance Link.

(4): 303-319.

Walker WR. 2013. The Transitional Costs of Sectoral Reallocation: Evidence From the Clean Air Act and the Workforce.

(4): 1787-1835

World-Bank. 2010. World Development Report 2010: Development and Climate Change.

This article is protected by copyright. All rights reserved. 


\section{Table 1. Summary statistics for key variables (main sample)}

\begin{tabular}{|c|c|c|c|c|c|c|c|c|}
\hline 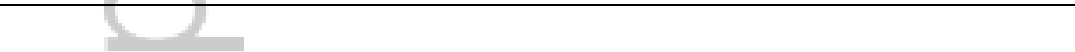 & Mean & SD & $(1)$ & $(2)$ & (3) & (4) & $(5)$ & (6) \\
\hline (1) $=$ Ln(Toxic emissions) & 12.98 & 6.09 & 1.00 & & & & & \\
\hline (2) LWC import share (Parent firm's share of imports from LWCs) & 0.16 & 0.19 & $-0.07 *$ & 1.00 & & & & \\
\hline (3) Plant's total value of shipment (in million dollars) & 175 & 586 & $0.18^{*}$ & $-0.06^{*}$ & 1.00 & & & \\
\hline (4) Skill intensity & 0.35 & 0.19 & $-0.09 *$ & $0.01 *$ & $-0.10 *$ & 1.00 & & \\
\hline (5) Total capital expenditures (in million dollars) & 6.13 & 36.0 & $0.18^{*}$ & $-0.08 *$ & $0.65^{*}$ & $-0.03 *$ & 1.00 & \\
\hline (6) Parent firm's total imports (in million dollars) & 711 & 3200 & $0.08 *$ & $-0.03 *$ & $0.34 *$ & $-0.03 *$ & $0.25^{*}$ & 1.00 \\
\hline
\end{tabular}

$\mathrm{N}=136 \mathrm{~K} .{ }^{*} \mathrm{p}<0.01$.

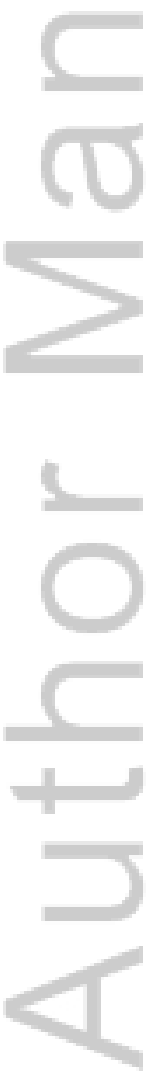

This article is protected by copyright. All rights reserved. 
Table 2. Firms' imports from LWCs and their U.S. plants' toxic emissions

\begin{tabular}{|c|c|c|c|c|c|c|}
\hline 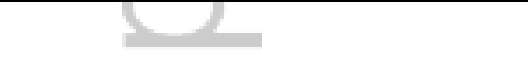 & \multicolumn{2}{|c|}{ Ln(Toxic emission) } & \multicolumn{2}{|c|}{ Ln(Toxic emission) } & \multirow{2}{*}{$\begin{array}{c}\operatorname{Ln}(\mathrm{RQ} \text { emission }) \\
(5)\end{array}$} & \multirow{2}{*}{$\begin{array}{l}\operatorname{Ln} \text { (Toxic emission) } \\
\text { (6) } 2 \text { SLS }\end{array}$} \\
\hline$= \pm$ & (1) & (2) & (3) & (4) & & \\
\hline LWC import share & $-0.583(0.000)$ & $-0.401(0.000)$ & & & $-0.112(0.075)$ & \\
\hline & {$[0.143]$} & {$[0.130]$} & & & [0.063] & \\
\hline Import share from China & & & $\begin{array}{l}-0.348 \\
(0.017) \\
{[0.146]}\end{array}$ & & & \\
\hline Import share from EU & & & $0.029(0.699)$ & & & \\
\hline & & & {$[0.075]$} & & & \\
\hline LWC import share, excluding China & & & & $-0.548(0.000)$ & & \\
\hline$=$ & & & & {$[0.191]$} & & \\
\hline LWC import share, instrumented & & & & & & $-0.772(0.039)$ \\
\hline & & & & & & {$[0.374]$} \\
\hline Ln(Plant output) & $0.449(0.000)$ & $0.451(0.000)$ & $0.451(0.000)$ & $0.452(0.000)$ & $0.238(0.000)$ & $0.450(0.000)$ \\
\hline & {$[0.035]$} & {$[0.035]$} & {$[0.035]$} & {$[0.025]$} & [0.015] & {$[0.035]$} \\
\hline Skill intensity & $-0.778(0.000)$ & $-0.703(0.000)$ & $\begin{array}{l}-0.702 \\
(0.000)\end{array}$ & $-0.708(0.000)$ & $-0.381(0.000)$ & $-0.786(0.000)$ \\
\hline 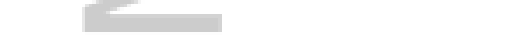 & {$[0.154]$} & {$[0.150]$} & {$[0.150]$} & {$[0.104]$} & {$[0.060]$} & {$[0.155]$} \\
\hline Ln(Capital expenditures) & $0.056(0.000)$ & $0.047(0.000)$ & $0.047(0.000)$ & $0.047(0.000)$ & $0.023(0.000)$ & $0.056(0.000)$ \\
\hline i & {$[0.009]$} & {$[0.009]$} & {$[0.009]$} & {$[0.007]$} & {$[0.004]$} & {$[0.009]$} \\
\hline Ln(Total imports) & $0.022(0.046)$ & $0.025(0.023)$ & $0.025(0.023)$ & $0.023(0.000)$ & $0.008(0.046)$ & $0.022(0.046)$ \\
\hline & {$[0.011]$} & {$[0.011]$} & {$[0.011]$} & {$[0.007]$} & {$[0.004]$} & {$[0.011]$} \\
\hline Year FE & Yes & No & No & No & No & Yes \\
\hline Industry*Year FE & No & Yes & Yes & Yes & Yes & No \\
\hline Plant FE & Yes & Yes & Yes & Yes & Yes & Yes \\
\hline Adjusted $\mathrm{R}^{2}$ & 0.712 & 0.715 & 0.715 & 0.715 & 0.790 & 0.712 \\
\hline
\end{tabular}

This table reports regression estimates of the correlation between firms' imports from LWCs and their plant-level toxic emissions in the U.S. in 1992-2009. $\mathrm{N}=136 \mathrm{~K}$, including all plants that are surveyed by TRI and with parent firms that import. Standard errors clustered at the firm level are included in square brackets. $p$-values are in parentheses. All tests are two-tailed.

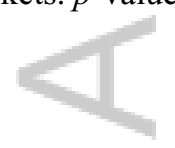

This article is protected by copyright. All rights reserved. 
Table 3. Firms' imports from LWCs and their U.S. plants' pollution-reduction efforts

\begin{tabular}{|c|c|c|c|c|c|}
\hline & $\begin{array}{l}\text { Abatement } \\
\text { Costs }\end{array}$ & $\begin{array}{l}\text { Abatement } \\
\text { Costs }\end{array}$ & $\begin{array}{l}\text { Pollution } \\
\text { prevention }\end{array}$ & $\begin{array}{c}\text { Total } \\
\text { production } \\
\text { waste (before } \\
\text { treatment) } \\
\text { (4) }\end{array}$ & $\begin{array}{c}\text { Fuel } \\
\text { consumption }\end{array}$ \\
\hline \multirow[t]{2}{*}{ LWC import share } & $-0.314(0.000)$ & $-0.738(0.000)$ & $0.036(0.444)$ & $-0.183(0.012)$ & $-0.196(0.000)$ \\
\hline & {$[0.097]$} & {$[0.238]$} & {$[0.047]$} & {$[0.073]$} & {$[0.064]$} \\
\hline \multirow[t]{2}{*}{ Ln(Plant output) } & $0.423(0.000)$ & $0.086(0.159)$ & $0.086(0.000)$ & $0.190(0.000)$ & $0.528(0.000)$ \\
\hline & {$[0.027]$} & {$[0.061]$} & {$[0.014]$} & {$[0.020]$} & {$[0.023]$} \\
\hline \multirow[t]{2}{*}{ Skill intensity } & $-1.504(0.000)$ & $-0.071(0.764)$ & $-0.068(0.303)$ & $-0.333(0.000)$ & $-0.095(0.286)$ \\
\hline & {$[0.092]$} & {$[0.237]$} & {$[0.066]$} & [0.091] & [0.089] \\
\hline \multirow{2}{*}{ Ln(Capital expenditures) } & $0.568(0.000)$ & $-0.440(0.000)$ & $0.026(0.000)$ & $0.025(0.000)$ & $0.038(0.000)$ \\
\hline & [0.023] & {$[0.063]$} & {$[0.005]$} & {$[0.006]$} & {$[0.006]$} \\
\hline \multirow[t]{2}{*}{ Ln(Total imports) } & $0.045(0.000)$ & $-0.050(0.000)$ & $0.001(0.803)$ & $0.012(0.046)$ & $-0.001(0.841)$ \\
\hline & {$[0.007]$} & {$[0.018]$} & {$[0.004]$} & {$[0.006]$} & {$[0.005]$} \\
\hline Industry*year FE & Yes & No & No & No & No \\
\hline Plant FE & No & Yes & Yes & Yes & Yes \\
\hline Adjusted $\mathrm{R}^{2}$ & 0.407 & 0.600 & 0.501 & 0.452 & 0.671 \\
\hline
\end{tabular}

$\mathrm{N}=50 \mathrm{~K}$ for Columns [1] and [2], including all plants that are surveyed by both TRI and PACE and with parent firms that import. $\mathrm{N}=136 \mathrm{~K}$ for Columns [3]-[5], including all plants that are surveyed by TRI and with parent firms that import. Standard errors are included in square brackets. $p$-values are in parentheses. All tests are two-tailed.

This article is protected by copyright. All rights reserved. 
Table 4. Firms' imports from LWCs and their pollution contents

\begin{tabular}{lcccc}
\hline & \multicolumn{2}{c}{ Ln(Toxic imports) } & \multicolumn{2}{c}{ Toxic imports } \\
& $(1)$ & $(2)$ & $(3)$ & $(4)$ \\
\hline LWC import share & $0.239(0.000)$ & $0.247(0.000)$ & $1.008(0.000)$ & $1.043(0.000)$ \\
& {$[0.028]$} & {$[0.028]$} & {$[0.280]$} & {$[0.281]$} \\
Ln(Firm size) & $0.028(0.000)$ & $0.026(0.000)$ & $-0.106(0.146)$ & $-0.129(0.077)$ \\
& {$[0.007]$} & {$[0.007]$} & {$[0.073]$} & {$[0.073]$} \\
Ln(Total imports) & $1.093(0.000)$ & $1.092(0.000)$ & $0.330(0.000)$ & $0.327(0.000)$ \\
& {$[0.004]$} & {$[0.004]$} & {$[0.042]$} & {$[0.042]$} \\
\hline Year FE & Yes & No & Yes & No \\
Industry*year FE & No & Yes & No & Yes \\
Firm FE & Yes & Yes & Yes & Yes \\
Adjusted R & 0.830 & 0.830 & 0.636 & 0.636 \\
\hline
\end{tabular}

This table reports regression estimates of the correlation between firms' imports from LWCs and the pollution intensity of their imports, from 1992 to 2009 . N=278K, including all firms that import. Standard errors clustered at the firm level are included in square brackets. $p$-values are in parentheses. All tests are two-tailed.

This article is protected by copyright. All rights reserved. 
Table 5. Firms' imports from LWCs and their U.S. plants' toxicity-weighted output

\begin{tabular}{lcccc}
\hline & \multicolumn{2}{c}{ Ln(Toxic output) } & \multicolumn{2}{c}{ Toxic output } \\
& $(1)$ & $(2)$ & $(3)$ & $(4)$ \\
\hline LWC import share & $-0.030(0.021)$ & $-0.030(0.124)$ & $-1.437(0.035)$ & $-1.595(0.019)$ \\
& {$[0.013]$} & {$[0.012]$} & {$[0.681]$} & {$[0.682]$} \\
Ln(Plant output) & $0.999(0.000)$ & $1.002(0.000)$ & $-1.502(0.260)$ & $-1.312(0.327)$ \\
& {$[0.003]$} & {$[0.003]$} & {$[1.333]$} & {$[1.338]$} \\
Skill intensity & $-0.030(0.021)$ & $-0.034(0.000)$ & $3.295(0.011)$ & $2.606(0.045)$ \\
& {$[0.013]$} & {$[0.013]$} & {$[1.302]$} & {$[1.299]$} \\
Ln(Capital expenditures) & $0.001(0.317)$ & $0.001(0.317)$ & $0.112(0.489)$ & $0.119(0.460)$ \\
& {$[0.001]$} & {$[0.001]$} & {$[0.162]$} & {$[0.161]$} \\
Ln(Total imports) & $0.001(0.617)$ & $0.0001(0.960)$ & $0.148(0.148)$ & $0.057(0.373)$ \\
& {$[0.002]$} & {$[0.002]$} & {$[0.064]$} & {$[0.064]$} \\
\hline Year FE & Yes & No & Yes & No \\
Industry*year FE & No & Yes & No & Yes \\
Plant FE & Yes & Yes & Yes & Yes \\
Adjusted R & 0.936 & 0.937 & 0.423 & 0.428
\end{tabular}

This table reports regression estimates of the impact of firms' imports from LWCs on their plant-level toxicityweighted output in the U.S. in 1992-2009. N=703K, including all plants with parent firms that import. Standard errors clustered at the firm level are included in square brackets. $p$-values are in parentheses. All tests are two-tailed.

This article is protected by copyright. All rights reserved. 
Table 6. Local institutional pressure and pollution offshoring

\begin{tabular}{lccc}
\hline & \multicolumn{3}{c}{ Local institutional pressure } \\
& College & Voter & Sierra Club \\
DV= Ln(Toxic emissions) & Education & Turnout & Membership \\
& $(1)$ & $(2)$ & $(3)$ \\
\hline LWC import share & $0.330(0.123)$ & $0.890(0.167)$ & $-2.352(0.000)$ \\
& {$[0.214]$} & {$[0.644]$} & {$[0.567]$} \\
Local institutional pressure & $-0.005(0.475)$ & $0.530(0.499)$ & $-0.144(0.201)$ \\
& {$[0.007]$} & {$[0.784]$} & {$[0.103]$} \\
LWC import share*Local institutional pressure & $-0.031(0.000)$ & $-3.158(0.162)$ & $-0.478(0.000)$ \\
& {$[0.009]$} & {$[1.554]$} & {$[0.138]$} \\
Ln(Plant output) & $0.451(0.000)$ & $0.454(0.000)$ & $0.453(0.000)$ \\
Skill intensity & {$[0.025]$} & {$[0.035]$} & {$[0.026]$} \\
& $-0.706(0.000)$ & $-0.721(0.000)$ & $-0.698(0.000)$ \\
Ln(Capital expenditures) & {$[0.105]$} & {$[0.151]$} & {$[0.105]$} \\
Ln(Total imports) & $0.047(0.000)$ & $0.046(0.000)$ & $0.047(0.000)$ \\
Andustry*year FE & {$[0.007]$} & {$[0.009]$} & {$[0.007]$} \\
\hline & $0.025(0.000)$ & $0.025(0.023)$ & $0.025(0.000)$ \\
& {$[0.007]$} & {$[0.011]$} & {$[0.007]$} \\
\hline
\end{tabular}

$\mathrm{N}=136 \mathrm{~K}$. The sample and control variables are the same as in Table 2. Standard errors are included in square brackets. $p$-values are in parentheses. All tests are two-tailed.

This article is protected by copyright. All rights reserved. 
Table 7.

Capability and pollution offshoring

Plant productivity

DV $=$ Ln(Toxic emissions)
(1)
Firm productivity

(2)
Firm R\&D and

brand equity

(3)

\begin{tabular}{|c|c|c|c|}
\hline LWC import share & $-1.408(0.000)$ & $-0.271(0.121)$ & $0.005(0.977)$ \\
\hline & {$[0.495]$} & {$[0.175]$} & {$[0.174]$} \\
\hline Capability & $-0.666(0.000)$ & $0.036(0.356)$ & $-0.014(0.046)$ \\
\hline$=$ & {$[0.046]$} & {$[0.039]$} & {$[0.007]$} \\
\hline LWC import share* Capability & $0.240(0.000)$ & $0.272(0.023)$ & $0.045(0.018)$ \\
\hline & {$[0.083]$} & {$[0.120]$} & [0.019] \\
\hline $\begin{array}{l}\text { Local institutional pressure } \\
\text { (Sierra Club membership) }\end{array}$ & $-0.501(0.242)$ & $-0.523(0.227)$ & $-0.186(0.733)$ \\
\hline & [0.428] & {$[0.433]$} & {$[0.546]$} \\
\hline $\begin{array}{l}\text { LWC import share*Local } \\
\text { institutional pressure }\end{array}$ & $-1.644(0.000)$ & $-1.396(0.025)$ & $-1.518(0.029)$ \\
\hline & {$[0.613]$} & {$[0.622]$} & [0.697] \\
\hline Ln(Plant output) & $0.833(0.000)$ & $0.452(0.000)$ & $0.522(0.000)$ \\
\hline & {$[0.038]$} & {$[0.026]$} & {$[0.036]$} \\
\hline Skill intensity & $-0.732(0.000)$ & $-0.678(0.000)$ & $-0.632(0.000)$ \\
\hline & {$[0.105]$} & {$[0.106]$} & {$[0.131]$} \\
\hline Ln(Capital expenditures) & $0.032(0.000)$ & $0.047(0.000)$ & $0.048(0.000)$ \\
\hline & {$[0.007]$} & {$[0.007]$} & {$[0.009]$} \\
\hline Ln(Total imports) & $0.023(0.000)$ & $0.023(0.000)$ & $0.025(0.000)$ \\
\hline & {$[0.007]$} & {$[0.007]$} & [0.009] \\
\hline Industry*year FE & Yes & Yes & Yes \\
\hline Plant FE & Yes & Yes & Yes \\
\hline Adjusted $\mathrm{R}^{2}$ & 0.715 & 0.715 & 0.730 \\
\hline
\end{tabular}

$\mathrm{N}=136 \mathrm{~K}$ for Columns (1) and (2), including the same plants as in Table 2. $\mathrm{N}=90 \mathrm{~K}$ for Column (3), including all plants that are surveyed by TRI and with parent firms that both import and are publicly listed. Standard errors are included in square brackets. $p$-values are in parentheses. All tests are two-tailed.

This article is protected by copyright. All rights reserved. 